\title{
PHARMACOPEIAL ASPECTS OF PREPARATION OF INFUSIONS AND DECOCTIONS IN PHARMACIES
}

\author{
Halyna Melnyk \\ Department of Drugs Technology $y^{l}$ \\ Tatyana Yarnykh $\bowtie$ \\ Department of Drugs Technology ${ }^{l}$ \\ tl@nuph.edu.ua \\ Marina Buryak \\ Department of Drugs Technology \\ ${ }^{I}$ National University of Pharmacy \\ 53 Pushkinska str., Kharkiv, Ukraine, 61002
}

$\triangle$ Corresponding author

\begin{abstract}
An analytical review of pharmacopoeial aspects of preparation of infusions and decoctions in pharmacies is presented.

The aim of this work is to conduct a comparative analysis of pharmacopoeial requirements for the technology of infusions and decoctions in pharmacies.

Materials and methods of the research. Comparative analysis of pharmacopoeial requirements was performed using methods of systematic and structural-logical analysis.

Results and discussions. It was found that in many pharmacopoeias (European, British, Italian, French, Czech, Kazakh) there are no instructions on the pharmacy technology of these dosage forms. Only the pharmacopoeias of Japan, Austria, Belarus and Russia contain separate monographs on the extemporaneous preparation of infusions and decoctions.

After analyzing these monographs, it was found that the definition of infusions and decoctions as a dosage form differs. It was found that the Japanese Pharmacopoeia regulates the preliminary preparation of medicinal plant raw materials (soaking for 5 minutes in water), in other pharmacopoeias there is no such requirement. When conducting a comparative analysis of the technology of preparation of infusions and decoctions, we observe that the ratio of medicinal plant raw materials (MPRM) and extractant and extraction modes differ.

Conclusions. An analytical review of pharmacopoeial aspects of preparation of infusions and decoctions in pharmacies is presented.

A comparative analysis of the requirements for technology and quality control of infusions and decoctions in accordance with pharmacopoeial articles revealed both different and similar information. The results of the research showed that despite the differences in the structures of articles and names, as well as approaches to the definition of this dosage form, some requirements are similar (particle size of MPRM). The differences that were found include the ratio of MPRM and extractant, extraction modes.

Taking into account the data of the analysis and the existing national requirements, the authors proposed a draft general pharmacopoeial article «Infusions and decoctions made in pharmacies».

Keywords: pharmacopoeias, monographs, pharmacopoeial articles, infusions, decoctions, medicinal plant raw materials, analysis, requirements, extemporaneous technology, quality indicators.
\end{abstract}

DOI: $10.21303 / 2504-5679.2021 .001971$

\section{Introduction}

In medical practice, an important place is occupied by herbal medicines, the share of which in the pharmaceutical market of developed countries reaches more than $50 \%$. Medicinal plant raw materials (MPRM) are widely used in medical practice. Of course, herbal medicines cannot completely replace therapy with drugs of synthetic origin, but can find effective use in the treatment of various diseases. In the preparation of medicines from plant raw materials, both individual substances isolated from plants and the whole complex of compounds contained in the raw materials total substances - are used. However, for the full use of herbal medicines in medical practice, it is necessary to clearly understand the fact that the standardization of MPRM and technology for the manufacture of phytopreparations is an important condition for their effective use [1]. 
Pharmaceutical development together with the fundamental elements of the quality assurance system (system of good practices) constitute the general system of quality assurance of medicines (Fig. 1).

\begin{tabular}{|c|}
\hline $\begin{array}{c}\text { The main purpose of pharmaceutical } \\
\text { development of drugs based on medicinal raw } \\
\text { materials }\end{array}$ \\
\hline $\begin{array}{l}\text { identification of the most important aspects that need to be controlled } \\
\text { during production }\end{array}$ \\
\hline $\begin{array}{l}\text { guaranteeing the probability that each unit of each batch of the } \\
\text { preparation to be manufactured will have a quality that will } \\
\text { correspond to its intended use }\end{array}$ \\
\hline purposeful formation of drug quality \\
\hline $\begin{array}{l}\text { defining the limits within which it is possible to change the process } \\
\text { after implementation to ensure the established pharmacological } \\
\text { action }\end{array}$ \\
\hline
\end{tabular}

Fig. 1. Components of quality assurance of pharmaceutical development of phytopreparations

In this regard, an important document for the rationing of manufacturing technology and quality indicators is the state pharmacopoeia or other regulations [2].

One of the simplest dosage forms of phytopreparations are infusions and decoctions.

It is worth noting that infusions and decoctions are one of the oldest dosage forms, which does not lose its significance due to its mild effect on the body, high bioavailability and relatively simple technology. These are liquid dosage forms, which are aqueous extracts from medicinal plant raw materials, as well as aqueous solutions of dry or liquid extracts (concentrates). They are widely used in medical practice both by themselves and as part of complex drugs in the form of potions, rinses, lotions, washes, baths, inhalations [2]. The purpose of obtaining extracts is the manufacture of convenient to use liquid dosage forms, and the most complete separation of biologically active substances from raw materials. The main factors influencing the rate and completeness of the release of active substances include [1]:

- the degree of grinding of raw materials;

- the ratio between the amount of raw materials and the volume of the finished extract;

- standard raw materials;

- histological structure of raw materials;

- temperature and infusion time;

- influence of enzymes and microflora;

- chemical composition of active substances;

$-\mathrm{pH}$ of the medium.

The aim of this work is to conduct a comparative analysis of pharmacopoeial requirements for the technology of infusions and decoctions in pharmacies.

\section{Materials and methods}

Comparative analysis of pharmacopoeial requirements was performed using methods of systematic and structural-logical analysis. World pharmacopoeias were used as objects of the research.

\section{Research results}

The leading role in the regulation of the pharmaceutical industry has a pharmacopoeia. Initially, pharmacopoeias, indeed, were collections of different drugs describing the method of their preparation. Modern pharmacopoeia is a collection of drug standards and gives only the basic principles of manufacturing dosage forms. 
The State Pharmacopoeia has a legislative nature that is mandatory for all pharmaceuticals, including veterinary institutions and enterprises of the country that manufacture, store, control and use drugs. The State Pharmacopoeia of Ukraine does not have a monograph «Infusions and decoctions made in pharmacies» [3-5]. Preparation of infusions and decoctions in pharmacies is regulated by regulations:

- by the order of the Ministry of Health of Ukraine No. 197 of September 7, 1993;

- guidelines «Requirements for the manufacture of non-sterile drugs in pharmacies» (approved by the order of the Ministry of Health of Ukraine from July 1, 2015 No. 398) [2].

Thus, it is advisable to develop a draft general pharmacopoeial article «Infusions and decoctions made in pharmacies». To solve this problem, it was necessary, first of all, to conduct a thorough analysis of the pharmacopoeial requirements of the world's major pharmacopoeias to the extemporaneous technology of infusions and decoctions.

To this end, we analyzed the European, British, Italian, French, Czech, Austrian, Japanese, Belarusian, Kazakh and Russian pharmacopoeias.

Analyzing this information revealed that in the pharmacopoeias where this article is present, the definition of this dosage form differs. Their analysis is presented in Table $\mathbf{1 .}$

Table 1

Comparative analysis of definitions of the dosage form «Infusions and decoctions» according to the monographs of world pharmacopoeias

\begin{tabular}{ll}
\hline Name of the pharmacopoeia & \multicolumn{1}{c}{ Definition } \\
\hline $\begin{array}{l}\text { SPhU XI «Infusions and de- } \\
\text { coctions», RP XIII «Infusions }\end{array}$ & as aqueous solutions of dry and liquid extracts (concentrates)». Medicinal substances, syrups, tinc- \\
$\begin{array}{l}\text { and decoctions» } \\
\text { Belarusian Pharmacopoeia }\end{array}$ & Infusions and decoctions - freshly prepared aqueous extracts from MPRM, species, herbal teas, as \\
«Infusions and decoctions» & well as «... aqueous solutions of dry or liquid extracts (concentrates) for internal and external use» \\
$\begin{array}{l}\text { Japanese Pharmacopoeia «In- } \\
\text { fusions and Decoctions» }\end{array}$ & $\begin{array}{l}\text { Infusions and decoctions - liquid drugs, usually obtained by maceration of medicinal plant raw } \\
\text { materials in water }\end{array}$ \\
$\begin{array}{ll}\text { European Pharmacopoeia } \\
\text { «Herbal teas, instant» }\end{array}$ & $\begin{array}{l}\text { Instant herbal teas consist of one or more herbal preparations (primarily extracts with or without } \\
\text { the addition of essential oils) and are intended for the preparation of a solution for oral administra- }\end{array}$ \\
tion immediately before use. May also contain in addition to vegetable raw materials, excipients \\
such as fillers (maltodextrin) and flavours
\end{tabular}

As can be seen from the data presented in Table 1, approaches to the definition of infusions and decoctions as dosage forms are different.

Analysis of pharmacopoeias showed that the article «Infusions and Decoctions» was included in all editions of the Russian Pharmacopoeia, starting with the first one (1866). It should be noted that in the early editions of the Pharmacopoeia, in addition to general articles, there were separate articles on infusions and decoctions of various types of MPRM [6-10].

Starting with the 10th edition (1968), separate articles on specific infusions and decoctions from the pharmacopoeia were excluded. The general article on these dosage forms, despite the development of analytical and pharmaceutical chemistry, in all editions of the Pharmacopoeia, up to XI, was a specific indication of the manufacturing technology (conditions of extraction, filtration, etc.) [7]. Described in the first edition, they passed into the next with minor additions. In general pharmacopoeial articles there were no quality indicators, not even organoleptic characteristics of aqueous extracts were given [7].

According to the Russian Pharmacopoeia, since 1936 (SP VIII) infusions and decoctions are prepared according to a certain technological scheme. The raw material is filled with water at room temperature, infused in a boiling water bath for 15 minutes (infusions) or 30 minutes (decoctions). It is then kept at room temperature for 45 minutes (infusions) or 10 minutes (decoctions) and filtered [6-10].

In RP XIII there is a general article 1.4.1.0018.15 «Infusions and decoctions» [6]. In it, in addition to the peculiarities of the technology, the indicators and quality criteria for the evaluation of this dosage form are regulated («Description», « 
The article on the preparation of infusions and decoctions in pharmacies was transferred to the Belarusian Pharmacopoeia from the Russian Pharmacopoeia of the XI edition in the same edition [11].

Analysis of the European Pharmacopoeia (EP) showed that the monograph on «Infusions and Decoctions» is absent. But in the EP, in the section «General monographs» there are three general monographs: «Medicinal herbal remedies», «Medicinal herbal raw materials» and «Medicinal herbal teas» [12]. They summarize the definitions of plant raw materials, medicines based on it, the requirements for their production, and tests for identification, purity and quantification. These articles are cited in full in the British, Italian, Czech and Kazakh pharmacopoeias [13-18].

There is also no general article on «Infusions and Decoctions» in the American Pharmacopoeia. However, in the section «General Chapters» there is an article «Vegetable drugs», which provides a method of sampling and a number of methods of pharmacognosy (impurities, common ash, etc.). The list of monographs includes articles on specific medicinal raw materials [19].

In the Japanese Pharmacopoeia, the section «General remarks» contains the article «General rules for crude Drugs», which includes a list of raw materials of plant and animal origin, as well as the article «Infusions and Decoctions» [20].

The article describes the general requirements for the size of MPRM and preparation of infusions and decoctions. Thus, in accordance with the requirements of the Japanese Pharmacopoeia: leaves, flowers and whole plants - coarse particles (Coarse cutting); woody stems, bark, roots and rhizomes - moderately fine particles (Moderately fine cutting); seeds and fruits - small particles.

According to the requirements of the pharmacopoeia, infusions are prepared by adding $50 \mathrm{ml}$ of purified water to 50.0 MPRM, followed by infusion for 15 minutes, then add $900 \mathrm{ml}$ of hot water and heat for 5 minutes, stirring. The resulting infusion is filtered.

Regarding the preparation of decoctions, the daily dose of MPRM is poured into 400-600 ml of purified water and heated for 30 minutes with stirring, then filtered. The resulting infusions and decoctions are packaged in tightly closed containers.

In the French Pharmacopoeia X edition there is a general article «Medicinal herbal raw materials», which differs in its wording from the EP, however, and here only briefly gives the concept of herbal raw materials and general requirements for quality control. Unfortunately, there is no information on the preparation of drugs with MPRM [21].

The Austrian Pharmacopoeia (Österreichisches arzneibuch) contains 3 general articles that regulate the preparation of infusions and decoctions, namely: Infusa «Aufgusse», Decocta «Abkochungen», Macerata «Mazerate» [22].

The articles pay special attention to the preliminary preparation of raw materials, a separate item determines the degree of grinding.

Leaves, flowers, grass are sifted through a sieve I (size of holes $-8000 \mu \mathrm{m}$ ). Woody plants, bark, roots, Iceland moss, Irish algae - sieve II (size of holes - $6000 \mu \mathrm{m}$ ). Fruits, seeds, plants containing alkaloids, blueberry leaves - sieve IV (hole size $-750 \mu \mathrm{m}$ ). Plants containing saponins, cardiac glycosides - sieve V (hole size - $300 \mu \mathrm{m}$ ).

Also in the articles of the Austrian Pharmacopoeia it is stated that before preparing the infusion and decoction of medicinal plant raw materials are soaked for 5 minutes in a mortar with a little water. If the medicinal plant raw material contains alkaloids, then during pre-treatment citric acid is added in an amount equal to the content of alkaloids. When using the bark of the quince tree use dilute hydrochloric acid in an amount of $0.5 \mathrm{ml}$ per $1 \mathrm{~g}$ of the drug.

To make infusions and decoctions, the crushed MPRM is placed in a porcelain infusion tube and infused in a water bath: the decoction for 30 minutes and the infusion for 5 minutes. The decoction is not cooled, and the infusion is cooled at room temperature for 30 minutes.

The ratio of raw materials and extractant is also clearly regulated. For all medicinal plant raw materials it is 1:10. The article Infusa «Aufgusse», Decocta «Abkochungen» states that the ratio of raw materials and extractant, as well as the degree of grinding can be changed only on the advice of a doctor.

Mucus is prepared in a ratio of 5 mass fractions of raw materials per $100 \mathrm{ml}$ of purified water.

The articles of the Austrian Pharmacopoeia also state that prepared infusions, decoctions and mucus must be labelled «Shake before use». 


\section{Discussion}

Thus, analyzing the technological process of preparation of infusions and decoctions, we observe that the ratio of MPRM and extractant and modes and duration of infusion differ [23-26].

The generalized data are given in Table 2.

Normative documentation used in Ukraine and regulating the extemporaneous technology of infusions and decoctions is currently represented only by the guideline «Requirements for the manufacture of non-sterile drugs in pharmacies» (approved by the order of the Ministry of Health of Ukraine from July 1, 2015 No. 398) [23]. The main approaches to the technology of infusions and decoctions in pharmacies are given in Table 3.

Annex B (mandatory) provides instructions for the manufacture of liquid drugs in pharmacies, which clearly regulates the technological process of preparation of infusions and decoctions [1].

\section{Table 2}

Comparative analysis of the ratio of components, modes of infusion preparation and decoctions according to the monographs of world pharmacopoeias

\begin{tabular}{|c|c|c|c|}
\hline \multirow{2}{*}{ Indicator } & \multicolumn{3}{|c|}{ Name of the pharmacopoeia } \\
\hline & Japan Pharmacopoeia & Austrian Pharmacopoeia & Russian Pharmacopoeia \\
\hline $\begin{array}{l}\text { Preliminary prepa- } \\
\text { ration of MPRM }\end{array}$ & $\begin{array}{l}\text { the degree of grinding is regu- } \\
\text { lated }\end{array}$ & $\begin{array}{l}\text { the degree of grinding is regulated, } \\
\text { before preparation MPRM soak in } \\
\text { a mortar for } 5 \text { min with a small } \\
\text { amount of the cleared water }\end{array}$ & the degree of grinding is regulated \\
\hline $\begin{array}{l}\text { MPRM:extractant } \\
\text { ratio }\end{array}$ & $\begin{array}{l}\text { infusion } 1: 1 \text {, followed by the ad- } \\
\text { dition of } 900 \mathrm{ml} \text { of hot water; } \\
\text { decoctions daily dose of MPRM } \\
\text { pour with } 400-600 \mathrm{ml} \text { of puri- } \\
\text { fied water }\end{array}$ & 1:10 & $\begin{array}{l}\text { depending on the chemical composition } \\
\text { of MPRM }\end{array}$ \\
\hline Preparation mode & $\begin{array}{l}\text { infusion } 15 \text { minutes at room } \\
\text { temperature in a water bath } \\
\text { for } 5 \text { minutes; } \\
\text { broths are heated for } 30 \text { minutes } \\
\text { with stirring }\end{array}$ & $\begin{array}{l}\text { infusions for } 5 \text { minutes in a water } \\
\text { bath, } 30 \text { minutes cooled at room } \\
\text { temperature; } \\
\text { decoctions for } 30 \text { minutes insist on } \\
\text { a water bath, do not cool }\end{array}$ & $\begin{array}{l}\text { Depending on the volume. } \\
\text { up to } 1000 \mathrm{ml} \text { of infusion for } 15 \text { minu- } \\
\text { tes in a water bath, cooled at room tem- } \\
\text { perature for } 45 \text { minutes; decoctions for } \\
30 \text { minutes in a water bath, cooled at } \\
\text { room temperature for } 10 \text { minutes }\end{array}$ \\
\hline
\end{tabular}

\section{Table 3}

Technological principles of extemporaneous production of infusions and decoctions

\begin{tabular}{|c|c|}
\hline Indicator & Description \\
\hline $\begin{array}{l}\text { Basic technologi- } \\
\text { cal instructions }\end{array}$ & $\begin{array}{l}\text { The calculated amount of crushed MPRM is poured into a metal/porcelain infusion tube and filled with } \\
\text { a certain volume of water. Decoctions infuse in a boiling water bath under a lid for } 30 \text { minutes, infusions - } \\
15 \text { minutes. After that, they are filtered (decoctions - after } 10 \text { minutes, and infusions - after } 45 \text { minutes), the } \\
\text { residue is squeezed and added to the extracts. Prepared infusions/decoctions are brought to the volume with } \\
\text { boiled water according to the recipe. Infusions are cooled for at least } 45 \text { minutes (because the API extraction } \\
\text { in most cases does not end during heating, and continues when the infusion is cooled). The need to strain the } \\
\text { decoctions after } 10 \text { minutes of cooling is due to the fact that the colloidal solutions contained in MPRM and } \\
\text { turn into decoctions, increase their viscosity and slow down the filtration. Infusions are prepared mainly from } \\
\text { aboveground MPRM (leaves, flowers, grass), decoctions - from underground (roots, rhizomes, bark). If the } \\
\text { volume of the water extract is more than } 1000-3000 \mathrm{ml} \text {, the heating time in the water bath is increased for } \\
\text { infusions up to } 25 \text { minutes, and for decoctions - up to } 40 \text { minutes. If the infusions/decoctions contain other } \\
\text { substances (salts, syrups, tinctures, extracts), they are added to the filtered infusions/decoctions; salts should } \\
\text { be only in dry form, because their addition in the form of concentrated solutions leads to dilution of extracts }\end{array}$ \\
\hline $\begin{array}{l}\text { Special cases of } \\
\text { preparation of } \\
\text { infusions and } \\
\text { decoctions }\end{array}$ & $\begin{array}{l}\text { Decoctions of the leaves of bearberry, root of Chinese rhubarb, rhizome of septfoil, oak bark and other MPRM } \\
\text { containing tannins, should be filtered immediately after removal from the water bath; decoctions of hay leaves } \\
\text { are filtered after complete cooling; } \\
\text { in the case of «cito» infusion in a water bath spend } 25 \text { minutes, and then the infusion is cooled artificially (wa- } \\
\text { ter or ice) }\end{array}$ \\
\hline Expiration date & Shelf life in a cool place - no more than 3 days \\
\hline
\end{tabular}


Analysis of the technological process of preparation of infusions and decoctions in pharmacies allows to develop a general algorithm for substantiation of their technology (Fig. 2).

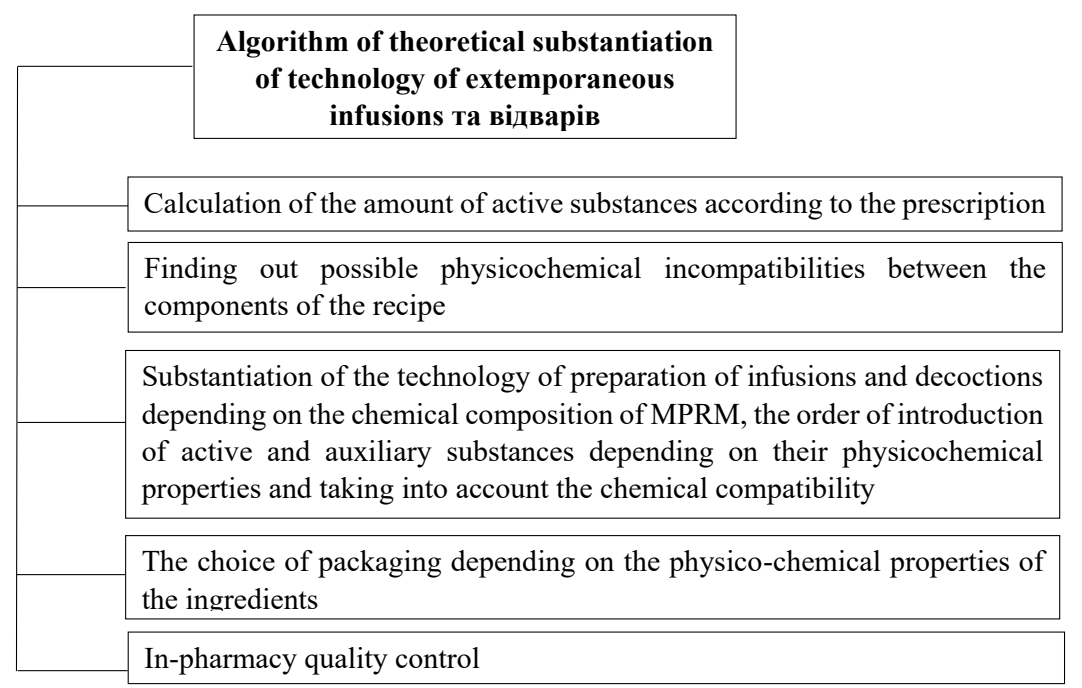

Fig. 2. Substantiation of technology of extemporaneous infusions and decoctions

Study limitations. The studies were limited to pharmacopoeias containing monographs on the dosage forms under study.

Prospects for further research. The presented algorithm of theoretical substantiation of the technology of extemporaneous infusions and decoctions will contribute to the standardization of the technological process and improve the quality of drugs.

\section{Conclusions}

An analytical review of pharmacopoeial aspects of preparation of infusions and decoctions in pharmacies is presented. It was found that in many pharmacopoeias (European, British, Italian, French, Czech, Kazakh) there are no instructions on the pharmacy technology of these dosage forms. Only the pharmacopoeias of Japan, Austria, Belarus and Russia contain separate monographs on the extemporaneous preparation of infusions and decoctions.

A comparative analysis of the requirements for technology and quality control of infusions and decoctions in accordance with pharmacopoeial articles revealed that despite the difference in the structures of articles and names, as well as approaches to determining this dosage form, some requirements are similar (MPRM particle size), but there are some differences (MPRM and extractant ratio, extraction modes). The analysis showed that the monograph «Infusions and Decoctions» of the Pharmacopoeia of Belarus and Russia are identical, and completely repeat this article from the Russian Pharmacopoeia XI edition.

The Austrian Pharmacopoeia contains 3 general articles that regulate the preparation of infusions and decoctions, namely: Infusa «Aufgusse», Decocta «Abkochungen», Macerata «Mazerate», which clearly regulates the particle size of MPRM, the ratio of raw materials and extractant, extraction mode. The article «Infusions and decoctions» of the Japanese Pharmacopoeia also provides clear information on the particle size of MPRM and the mode of extraction.

The results of the research will be taken into account by the authors in the development of the monograph of the SPhU «Infusions and decoctions made in the pharmacy».

\section{Conflict of interest}

The authors declare that they have no conflicts of interest.

\section{Financing}

The study was performed without financial support. 


\section{References}

[1] Tykhonov, O. I., Yarnykh, T. H.; Tykhonov, O. I. (Ed.) (2016). Aptechna tekhnolohiia likiv. Vinnytsia: Nova Knyha, 536.

[2] Vymohy do vyhotovlennia nesterylnykh likarskykh zasobiv v umovakh aptek: nastanova ST-N MOZU 42-4.5:2015 (2015). Zatverdzheni Nakazom MOZ Ukrainy No. 398. 01.07.15. Kyiv, 109. Available at: https://tl.nuph.edu.ua/wp-content/ uploads/2020/06/Вимоги-до-виготовлення-нестерильних-лікарських-засобів-умовах-аптек.pdf

[3] Derzhavna Farmakopeia Ukrainy. Vol. 1 (2015). Kharkiv: Derzh. p-vo «Ukr. nauk. farmakopeinyi tsentr yakosti likarskykh zasobiv», 1128.

[4] Derzhavna Farmakopeia Ukrainy. Vol. 2 (2014). Kharkiv: Derzh. p-vo «Ukr. nauk. farmakopeinyi tsentr yakosti likarskykh zasobiv», 724.

[5] Derzhavna Farmakopeia Ukrainy. Vol. 3 (2014). Kharkiv: Derzh. p-vo «Ukr. nauk. farmakopeinyi tsentr yakosti likarskykh zasobiv», 732.

[6] Gosudarstvennaya farmakopeya Rossiyskoy Federatsii XIII izd. Vol. 1-3 (2015). Moscow, 704.

[7] Gosudarstvennaya farmakopeya SSSR: Vyp. 2. Obschie metody analiza. Lekarstvennoe rastitelnoe syre (1989). Moscow: Meditsina, 400.

[8] Gosudarstvennaya farmanopeya SSSR. 10-ed. (1968). Moscow: Meditsina.

[9] Gosudarstvennaya farmanopeya SSSR. 8-ed. (1952). Moscow: Medgiz.

[10] Gosudarstvennaya farmanopeya SSSR. 9-ed. (1961). Moscow: Medgiz.

[11] Gosudarstvennaya farmakopeya Respubliki Belarus (2007). Vol. 2. Minsk: Ministerstvo zdravookhraneniya Respubliki Belarus, 471.

[12] Council of Europe. European Pharmacopoeia (2020). Strasbourg: Council of Europe. Available at: https://www.edqm.eu/en/ european-pharmacopoeia-ph-eur-10th-edition

[13] British Pharmacopoeia 2020. London: The Stationary Office on behalf of the Medicines and Healthcare products Regulatory Agency (MHRA).

[14] Pharmacopea ufficiale della Republica Italiano, XII ed. (2018). Roma, 1568.

[15] Český lékopis 2017. Praga: Grada Publishing, spol. s. r. o., 2017, EDQM.

[16] Gosudarstvennaya farmakopeya Respubliki Kazakhstan. Vol. I (2008). Almaty: Zhibek zholy.

[17] Gosudarstvennaya farmakopeya Respubliki Kazakhstan. Vol. II (2008). Almaty: ZHibek zholy.

[18] Gosudarstvennaya farmakopeya Respubliki Kazakhstan. Vol. III (2014). Almaty: ZHibek zholy.

[19] The United States Pharmacopeia 42 - NationalFormulary 37 (2020). Washington: The United States Pharmacopeial Convention. Available at: https://www.worldcat.org/title/united-states-pharmacopoeia-the-national-formulary/oclc/1167504175\&referer=brief_results

[20] The Japanese Pharmacopeia, XVII ed. (2016). Available at: https:/www.pmda.go.jp/english/rs-sb-std/standards-development/ jp/0019.html

[21] Pharmacopee Française, XI ed. (2016). Paris. Available at: https://ansm.sante.fr/Mediatheque/Publications/Pharmacopee-francaise-Substances-d-origine-vegetale

[22] Österreichisches arzneibuch. Wien 2006. (2006). Druck: Verlag Österreich GmbH. 560.

[23] Yarnykh, T. G., Rukhmakova, O. A. (2015). Peculiarities of the Technology, Quality Control, and Pharmaceutical Development of Extemporaneous Preparations for Children. Pharmaceutical Chemistry Journal, 49 (2), 122-124. doi: http://doi.org/10.1007/ s11094-015-1234-8

[24] Jain, S. K. (2011). Stability protocols for different dosage forms. Magalayatan University.

[25] Sarma, N., Giancaspro, G., Venema, J. (2016). Dietary supplements quality analysis tools from the United States Pharmacopeia. Drug Testing and Analysis, 8 (3-4), 418-423. doi: http://doi.org/10.1002/dta.1940

[26] Tabajara de Oliveira Martins, D., Rodrigues, E., Casu, L., Benítez, G., Leonti, M. (2019). The historical development of pharmacopoeias and the inclusion of exotic herbal drugs with a focus on Europe and Brazil. Journal of Ethnopharmacology, 240, 111891. doi: http://doi.org/10.1016/j.jep.2019.111891

Received date 31.05.2021

(C) The Author(s) 2021

Accepted date 16.07.2021

This is an open access article

Published date 30.07.2021 under the Creative Commons CC BY license

How to cite: Melnyk, H., Yarnykh, T., Buryak, M. (2021). Pharmacopeial aspects of preparation of infusions and decoctions in pharmacies. EUREKA: Health Sciences, 4, 87-93. doi: http://doi.org/10.21303/2504-5679.2021.001971 